\title{
NOVEL STABILITY-INDICATING HIGH-PERFORMANCE LIQUID CHROMATOGRAPHIC ASSAY METHOD FOR SIMULTANEOUS ESTIMATION OF HYDROCORTISONE AND TETRACYCLINE IN BULK AND PHARMACEUTICAL DOSAGE FORM
}

\author{
MUNI SAI VARAGANTI, PRASANTHI CHENGALVA*, ARUNA GUNDALA \\ Department of Pharmaceutical Analysis, Krishna Teja Pharmacy College, Tirupati, Andhra Pradesh, India.
}

Email: prashanthi.chengalva87@gmail.com

Received: 14 August 2019, Revised and Accepted: 07 September 2019

\begin{abstract}
Objective: A combination of hydrocortisone and tetracycline as topical ophthalmic ointment is used for skin irritations, eye infections, inflammation, skin infections, acne, and rashes. The objective of the current work is to a simple, rapid, accurate, and precise, stability-indicating reverse-phase liquid chromatographic method was developed for the simultaneous estimation of hydrocortisone and tetracycline in bulk and pharmaceutical dosage form.

Methods: The separation was carried out in Discovery C18 column $(250 \times 4.6 \mathrm{~mm}, 5 \mu \mathrm{m})$ using mobile phase ratio of water (pH 2.2 adjusted with orthophosphoric acid):acetonitrile $(40: 60 \mathrm{v} / \mathrm{v})$ in an isocratic elution mode with a flow rate of $1.0 \mathrm{ml} / \mathrm{min}$ at detection wavelength of $244 \mathrm{~nm}$. The injection volume was $10 \mu \mathrm{l}$ and the column temperature was set at $30^{\circ} \mathrm{C}$.

Results: The retention time for hydrocortisone and tetracycline was found to be $2.214 \pm 0.001$ min and $3.497 \pm 0.001$ min, respectively. Calibration curves were linear $\left(\mathrm{r}^{2}=0.999\right)$ at a concentration range of $2.5-15 \mathrm{mg} / \mathrm{ml}$ for both hydrocortisone and tetracycline. The percentage recoveries were found to be $99.13-99.67 \%$ for hydrocortisone and $99.39-99.61 \%$ for tetracycline. Relative standard deviation was found to be $0.3 \%$ for both the drugs. Limit of detection and limit of quantification values of hydrocortisone and tetracycline were found to be $0.09 \mu \mathrm{g} / \mathrm{ml}$ and $0.27 \mu \mathrm{g} / \mathrm{ml}$ and $0.17 \mu \mathrm{g} / \mathrm{ml}$ and $0.52 \mu \mathrm{g} / \mathrm{ml}$, respectively. The drugs were subjected to various stress conditions and found no interference of degraded products peak at the retention times of analyte peaks.
\end{abstract}

Conclusion: A rapid and accurate reverse-phase high-performance liquid chromatographic method was developed for simultaneous estimation of hydrocortisone and tetracycline, and the method was validated as per the International Council for Harmonization guidelines. Hence, the developed method can be successfully applied for the simultaneous estimation of hydrocortisone and tetracycline in bulk and ointment formulation.

Keywords: Hydrocortisone, Tetracycline, Stability-indicating reverse-phase high-performance liquid chromatographic, Method development, Method validation.

(C) 2019 The Authors. Published by Innovare Academic Sciences Pvt Ltd. This is an open access article under the CC BY license (http://creativecommons. org/licenses/by/4. 0/) DOI: http://dx.doi.org/10.22159/ajpcr.2019.v12i10.35343

\section{INTRODUCTION}

Hydrocortisone (Fig. 1) is chemically (8S,9S,10R,11S,13S,14S,17R)11,17-dihydroxy-17-(2-hydroxyacetyl)-10,13-dimethyl2,6,7,8,9,11,12,14,15,16-decahydro-cyclopenta[a]phenanthren-3-one. It is a synthetic corticosteroid that can be administered into the eyes to decrease the inflammation. It works by acting within cells to decrease the release of these substances in a particular area, thereby reducing swelling, redness, and itching. Tetracycline (Fig. 2) is chemically ( $4 \mathrm{~S}, 4 \mathrm{aS}, 5 \mathrm{aS}, 6 \mathrm{~S}, 12 \mathrm{aR})$-4-(dimethylamino)-1,6,10,11,12apentahydroxy-6-methyl-3,12-dioxo-4,4a,5,5a-tetrahydrotetracene-2carboxamide. It is a broad-spectrum naphthacene antibiotic, binds to 30 S subunit of bacterial ribosome [1]. It interferes with the binding of aminoacyl-tRNA to the mRNA-ribosome complex, thereby inhibiting protein synthesis.

Extensive literature survey revealed that there were ultraviolet (UV) spectroscopic methods for the estimation of hydrocortisone and with other combinations [2,3]. Few reverse-phase highperformance liquid chromatographic (RP-HPLC) methods were reported for the estimation of hydrocortisone alone and with other combinations [4-7]. A high-performance liquid chromatographic tandem mass spectrometric method for the estimation of hydrocortisone in human urine has been reported [8] and a highperformance thin-layer chromatographic method has been reported for quantification of hydrocortisone and clotrimazole [9]. Along with these RP-HPLC methods have reported for the estimation of tetracycline $[10,11]$. However, no RP-HPLC method has been reported for the simultaneous assay of specified drugs in bulk and pharmaceutical formulation. Therefore, it was thought propitious to develop HPLC procedure that serves as a rapid, accurate, and simple method for the simultaneous estimation of hydrocortisone and tetracycline in bulk and pharmaceutical formulation.

\section{METHODS}

\section{Chemicals and reagents}

Reference standards of hydrocortisone and tetracycline were obtained as gift samples from Spectrum Pharma Research Solutions (Hyderabad, India). HPLC grade acetonitrile, water (Milli-Q), and chemicals of AR grade were procured from Merck (Mumbai). Pharmaceutical dosage form (Cortecycline ointment) was obtained as a gift sample from Syntho Pharmaceuticals Pvt. Ltd. (India).

\section{Instrumentation}

Waters HPLC 2695 system equipped with quaternary pumps and photodiode array detector, Discovery C18 column $(4.5 \times 250 \mathrm{~mm} \times 5 \mu \mathrm{m})$ was employed for the study. The data acquisition and integration were performed using Empower 2 software.

\section{Optimized chromatographic conditions}

Separation was achieved on a Discovery C18 $(250 \times 4.6 \mathrm{~mm}, 5 \mu \mathrm{m})$ column at wavelength of $244 \mathrm{~nm}$, using mobile phase water $(\mathrm{pH} 2.2$ 
adjusted with orthophosphoric acid [OPA]):acetonitrile (40:60) in an isocratic elution mode with an injection volume $10 \mu \mathrm{l}$ at a flow rate of $1.0 \mathrm{ml} / \mathrm{min}$. The column temperature was set at $30^{\circ} \mathrm{C}$.

Diluent

Acetonitrile and water in the ratio of 50:50 were used as diluent.

\section{Preparation of standard solution}

The standard stock solution was prepared by accurately weighing $2.5 \mathrm{mg}$ of hydrocortisone and $2.5 \mathrm{mg}$ of tetracycline standards and transferred into $25 \mathrm{ml}$ clean dry volumetric flask, $10 \mathrm{ml}$ of diluent was added, sonicated for $10 \mathrm{~min}$, and made up to the final volume with diluent. $1 \mathrm{ml}$<smiles>CCCC(=O)OCC(=O)[C@]1(O)CC[C@H]2[C@@H]3CCC4=CC(=O)CC[C@]4(C)[C@H]3[C@H](O)C[C@]21C</smiles>

Fig. 1: Chemical structure of hydrocortisone<smiles>CN(C)[C@H]1C(O)=C(C(N)=O)C(=O)[C@]2(O)C(O)=C3C(=O)c4c(O)cccc4[C@@H](O)[C@@]3(C)C[C@H]12</smiles>

Fig. 2: Chemical structure of tetracycline

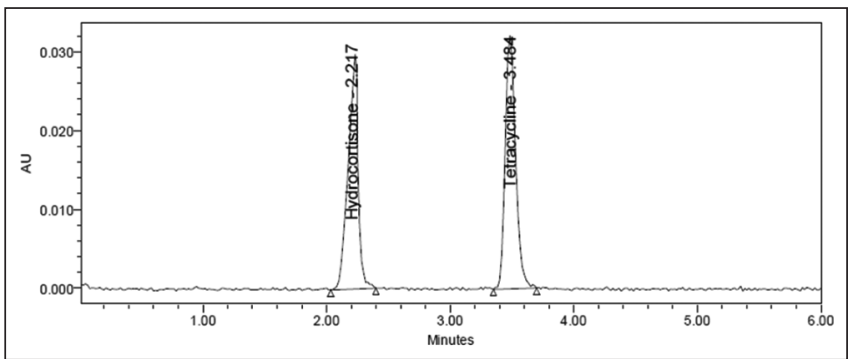

Fig. 3: Standard chromatogram of hydrocortisone and tetracycline

Table 1: Results of system suitability

\begin{tabular}{llll}
\hline Parameters & Hydrocortisone & Tetracycline & Limits \\
\hline Retention time & $2.214 \pm 0.001$ & $3.497 \pm 0.001$ & - \\
Resolution & - & 8.2 & NLT 2 \\
Theoretical plates & 3496.4 & 8592.7 & NLT 2000 \\
Tailing factor & 0.9 & 1.2 & NMT 2 \\
\hline
\end{tabular}

NLT: Not less than; NMT: Not more than from the above stock solution was taken into a $10 \mathrm{ml}$ volumetric flask and made up to the volume with diluent to get a final concentration of $10 \mu \mathrm{g} / \mathrm{ml}$ of hydrocortisone and $10 \mu \mathrm{g} / \mathrm{ml}$ of tetracycline.

\section{Preparation of sample preparation}

The sample solution was prepared by taking $3 \mathrm{~g}$ of ointment, transferred into motor, triturated for $5 \mathrm{~min}$, from this, $1 \mathrm{~g}$ of ointment was weighed and transferred to a $100 \mathrm{ml}$ volumetric flask. To this, $10 \mathrm{ml}$ of glacial acetic acid was added and stirred for $40 \mathrm{~min}$ on a magnetic stirrer and made up to mark with methanol and then it was centrifuged for $20 \mathrm{~min}$. The supernatant was collected and filtered using $0.45 \mu \mathrm{m}$ filters. From this, $1 \mathrm{ml}$ of filtered stock solution was taken, transferred to $10 \mathrm{ml}$ of volumetric flask, and made up with diluent.

\section{Method validation \\ Linearity}

Linearity of the developed method was established at concentration levels from $50 \%$ to $150 \%$ of target assay concentration. The corresponding peak areas were noted and the data were subjected to least square regression analysis. From this, limit of detection (LOD) and limit of quantification (LOQ) values were calculated using the formula method as given in International Council for Harmonization (ICH) guidelines [12].

\section{Precision}

The precision of the assay method was determined by repeatability which was evaluated at $100 \%$ concentration level. Six determinations were performed and the percentage relative standard deviation (RSD) was calculated.

\section{Accuracy}

The accuracy of the assay method was evaluated by recovery studies in triplicate at three concentration levels $(50,100$, and $150 \%)$ by the following standard addition method and the percentage recoveries were calculated.

\section{Robustness}

The robustness of the assay method was established by introducing small but deliberate alterations in the optimized chromatographic conditions such as flow rate $( \pm 0.1 \mathrm{ml} / \mathrm{min})$, temperature $\left( \pm 2^{\circ} \mathrm{C}\right)$, and mobile phase ratio $( \pm 5 \%)$ and system suitability parameters were evaluated.

\section{Forced degradation studies}

Stress degradation was carried out to check the specificity of the developed method. The drugs were subjected to various stress conditions such as acid, alkali, oxidative, photolytic, and thermal conditions recommended by ICH guidelines. The degraded products were generated and analyzed. For acid degradation studies, $1 \mathrm{ml}$ of 2 $\mathrm{N} \mathrm{HCl}$ was added to $1 \mathrm{ml}$ of stock solution and refluxed for $30 \mathrm{~min}$ at $60^{\circ} \mathrm{C}$. To this, $1 \mathrm{ml}$ of $2 \mathrm{~N} \mathrm{NaOH}$ was added to neutralize the resultant solution and was diluted to $10 \mathrm{ml}$ with diluent. For alkali degradation studies, $1 \mathrm{ml}$ of $2 \mathrm{~N} \mathrm{NaOH}$ was added $1 \mathrm{ml}$ of stock solution and refluxed for $30 \mathrm{~min}$ at $60^{\circ} \mathrm{C}$. To this, $1 \mathrm{ml}$ of $2 \mathrm{~N} \mathrm{HCl}$ was added to neutralize the resultant solution and was diluted to $10 \mathrm{ml}$ with diluent. For oxidative degradation, $1 \mathrm{ml}$ of $20 \%$ hydrogen peroxide was added to $1 \mathrm{ml}$ of

Table 2: Results of linearity

\begin{tabular}{|c|c|c|c|c|}
\hline \multirow[t]{2}{*}{$\%$ level } & \multicolumn{2}{|l|}{ Hydrocortisone } & \multicolumn{2}{|l|}{ Tetracycline } \\
\hline & Concentration $(\mu \mathrm{g} / \mathrm{ml})$ & Peak area & Concentration $(\mu \mathrm{g} / \mathrm{ml})$ & Peak area \\
\hline 25 & 2.5 & 34,761 & 2.5 & 36,433 \\
\hline 50 & 5 & 68,112 & 5 & 70,737 \\
\hline 75 & 7.5 & 102,414 & 7.5 & 104,963 \\
\hline 100 & 10 & 136,463 & 10 & 139,559 \\
\hline 125 & 12.5 & 169,209 & 12.5 & 175,085 \\
\hline 150 & 15 & 201,466 & 15 & 210,225 \\
\hline Correlation coefficient $\left(\mathrm{r}^{2}\right)$ & 0.999 & & 0.999 & \\
\hline
\end{tabular}


standard stock solution. The solution was kept for $30 \mathrm{~min}$ at $60^{\circ} \mathrm{C}$. The resultant solution was diluted to $10 \mathrm{ml}$ with diluent. For thermal degradation, the standard stock solution was taken in a beaker and placed in oven at $105^{\circ} \mathrm{C}$ for $1 \mathrm{~h}$ and $1 \mathrm{ml}$ from the resultant solution was diluted to $10 \mathrm{ml}$ with diluent. For photo stability studies, the standard drug solution was exposed to UV light by keeping the beaker in UV

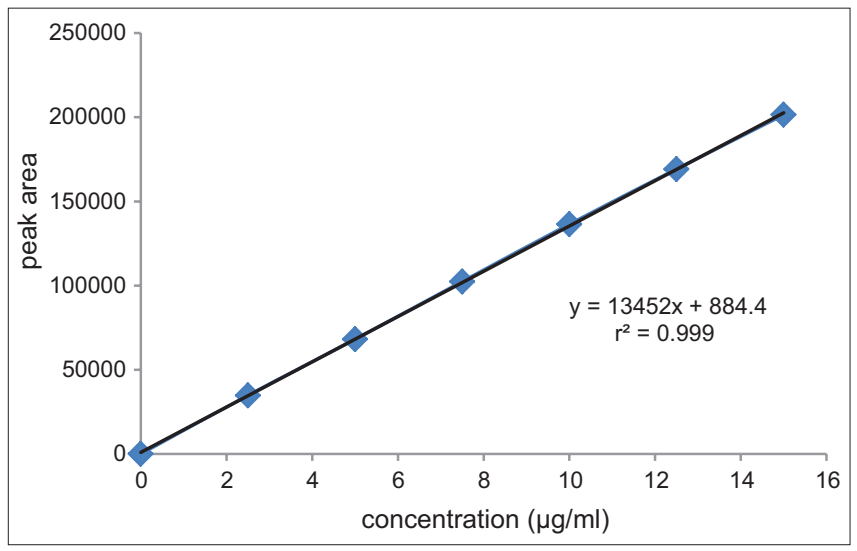

Fig. 4: Calibration curve of hydrocortisone

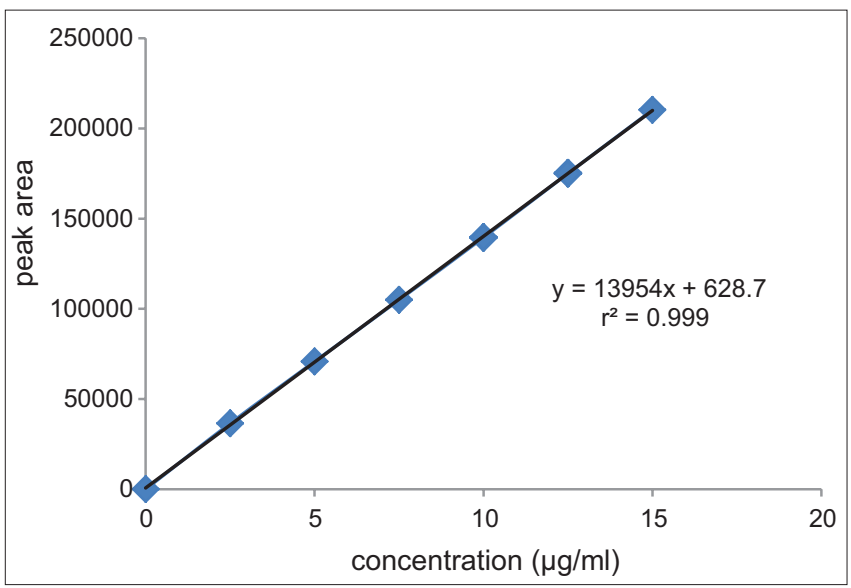

Fig. 5: Calibration curve of tetracycline

Table 3: Results of accuracy

\begin{tabular}{lll}
\hline Level (\%) & Hydrocortisone & Tetracycline \\
\cline { 2 - 2 } & Mean recovery* & Mean recovery* \\
\hline 50 & 99.67 & 99.39 \\
100 & 99.13 & 99.61 \\
150 & 99.19 & 99.44 \\
\hline
\end{tabular}

*Represents mean of three determinations chamber for 1 day, from the resultant solution $1 \mathrm{ml}$ was taken and diluted up to $10 \mathrm{ml}$ with diluent.

\section{Assay of formulation}

Applicability of the developed method can be done by assaying the formulation. For this, standard preparations were made from the reference standard and sample preparations were from formulation. Both sample and standards are injected 6 times into the chromatographic system. Amount of drug present in the formulation was estimated by taking the standard as the reference. The percentage assay was calculated.

\section{RESULTS AND DISCUSSION}

\section{Method development}

A novel analytical method was established for the simultaneous estimation of hydrocortisone and tetracycline. Sharp and highly resolved peaks were obtained using Discovery C18 column $(250 \mathrm{~mm} \times 4.6 \mathrm{~mm}, 5 \mu \mathrm{m})$ at detector wavelength of $244 \mathrm{~nm}$. The mobile phase containing water ( $\mathrm{pH}$ adjusted to 2.2 with $\mathrm{OPA})$ :acetonitrile $(40: 60 \% \mathrm{v} / \mathrm{v})$ was pumped at a flow rate of $1 \mathrm{ml} / \mathrm{min}$. The column temperature was set at $30^{\circ} \mathrm{C}$. The standard and sample chromatograms were presented (Fig. 3). All the system suitability parameters such as theoretical plates, resolution, and tailing factor were found to be within the limits and are summarized in Table 1 .

\section{Method validation}

The developed method was validated for parameters such as system suitability, specificity, linearity, accuracy, precision, LOD, LOQ and robustness according to ICH guidelines for analytical procedures.

\section{Specificity}

Specificity of the method was determined by injecting blank, placebo, and degraded samples under similar chromatographic conditions. No interfering peaks were found at retention times of analyte peaks.

\section{Linearity and range}

The linearity was developed at six concentration levels from $25 \%$ to $150 \%$ within the concentration range of $2.5-15 \mu \mathrm{g} / \mathrm{ml}$ for hydrocortisone and tetracycline. The results of linearity of are tabulated in Table 2 . The correlation coefficients were found to be 0.999 for both drugs and the representative calibration plots were shown (Fig. 4 and 5) which met the method validation acceptance criteria, and hence, the method was said to be linear for both the drugs in the specified concentration range.

\section{Accuracy}

For the evaluation of accuracy, the percentage recoveries were calculated for both the drugs and presented in Table 3. The recovery values indicate that the developed method was found to be accurate.

\section{Precision}

The results of precision are tabulated in Table 4. RSD was calculated and reported. RSD values were found to be $<2 \%$ clearly assured that the developed method was found to be precise.

Table 4: Results of precision studies

\begin{tabular}{|c|c|c|c|c|}
\hline \multirow[t]{2}{*}{ Number of injections } & \multicolumn{2}{|l|}{ Hydrocortisone } & \multicolumn{2}{|l|}{ Tetracycline } \\
\hline & Retention time & Peak area & Retention time & Peak area \\
\hline 1 & 2.201 & 136,355 & 3.484 & 138,455 \\
\hline 2 & 2.209 & 136,725 & 3.495 & 138,525 \\
\hline 3 & 2.214 & 135,808 & 3.496 & 138,308 \\
\hline 4 & 2.214 & 135,799 & 3.496 & 138,599 \\
\hline 5 & 2.214 & 135,790 & 3.497 & 139,190 \\
\hline 6 & 2.215 & 135,783 & 3.498 & 139,083 \\
\hline Mean* \pm SD & & $136,043 \pm 402.2$ & & $139,693 \pm 358.1$ \\
\hline RSD & & 0.3 & & 0.3 \\
\hline
\end{tabular}

*Mean of six determinations. SD: Standard deviation, RSD: Relative standard deviation 
Table 5: Results of robustness

\begin{tabular}{|c|c|c|c|c|}
\hline \multirow[t]{2}{*}{ Parameter } & \multicolumn{2}{|c|}{ Hydrocortisone } & \multicolumn{2}{|c|}{ Tetracycline } \\
\hline & Tailing & $\begin{array}{l}\text { Plate } \\
\text { count }\end{array}$ & Tailing & $\begin{array}{l}\text { Plate } \\
\text { count }\end{array}$ \\
\hline $\begin{array}{l}\text { Less flow rate } \\
(0.9 \mathrm{ml} / \mathrm{min})\end{array}$ & 0.90 & 3434 & 0.90 & 7838 \\
\hline $\begin{array}{l}\text { More flow rate } \\
(1.1 \mathrm{ml} / \mathrm{min})\end{array}$ & 1.10 & 3335 & 1.10 & 7641 \\
\hline $\begin{array}{l}\text { Less column temperature } \\
\left(28^{\circ} \mathrm{C}\right)\end{array}$ & 0.91 & 3426 & 1.20 & 8170 \\
\hline $\begin{array}{l}\text { More column temperature } \\
\left(32^{\circ} \mathrm{C}\right)\end{array}$ & 0.89 & 3137 & 1.22 & 8229 \\
\hline $\begin{array}{l}\text { Less organic phase } \\
(45: 55)\end{array}$ & 0.87 & 2665 & 1.21 & 8002 \\
\hline $\begin{array}{l}\text { More organic phase } \\
(35: 65)\end{array}$ & 0.93 & 3849 & 1.18 & 7959 \\
\hline
\end{tabular}

Table 6: Results of forced degradation studies

\begin{tabular}{llllll}
\hline \multirow{2}{*}{$\begin{array}{l}\text { Type of } \\
\text { degradation }\end{array}$} & \multicolumn{2}{l}{ Hydrocortisone } & & \multicolumn{2}{l}{ Tetracycline } \\
\cline { 2 - 3 } \cline { 5 - 6 } & $\begin{array}{l}\text { Purity } \\
\text { angle }\end{array}$ & $\begin{array}{l}\text { Purity } \\
\text { threshold }\end{array}$ & & $\begin{array}{l}\text { Purity } \\
\text { angle }\end{array}$ & $\begin{array}{l}\text { Purity } \\
\text { threshold }\end{array}$ \\
\hline Acid & 0.695 & 1.495 & & 0.172 & 1.257 \\
Base & 0.695 & 1.495 & & 0.172 & 1.257 \\
Peroxide & 1.075 & 1.694 & & 1.383 & 1.533 \\
Thermal & 2.258 & 3.572 & & 0.542 & 0.868 \\
UV & 1.150 & 3.273 & & 0.654 & 0.874 \\
\hline
\end{tabular}

UV: Ultraviolet

$\angle O D$ and $L O Q$

LOD and LOQ were evaluated from the standard deviation of the Y intercepts and slope of the calibration curve of hydrocortisone and tetracycline by formula method calibration curves. The LOD and LOQ values were found to be $0.09 \mu \mathrm{g} / \mathrm{ml}$ and $0.27 \mu \mathrm{g} / \mathrm{ml}$ and $0.17 \mu \mathrm{g} / \mathrm{ml}$ and $0.52 \mu \mathrm{g} / \mathrm{ml}$ for hydrocortisone and tetracycline, respectively. The results indicate the sensitivity of the developed method.

\section{Robustness}

Robustness of the developed method was determined by varying conditions such as flow rate, temperature, and organic phase ratios; system suitability parameters were compared with that of method. The results are tabulated in Table 5. Small changes in the conditions have no significant effect on tailing, plate count, and retention time of specified drugs. Hence, the developed method was found to be robust.

\section{Forced degradation studies}

The purity angle of the analyte components under various stress conditions was less than the threshold values, indicating spectral homogeneity across the peak. The results of forced degradation studies are presented in Table 6. The purity angle values were less than that of purity threshold values. The results specify that there was no interference of degraded peaks with analyte peaks. Hence, the method has successfully resolved the degraded component peaks.

\section{Assay of formulation}

The applicability of developed method can be done by assaying the formulation. Cortecycline ointment was assayed and the mean percentage recovery was found to be $99.35 \%$ and $99.48 \%$ for hydrocortisone and tetracycline, respectively, and hence, the method was successfully employed for the assay of available formulation.

\section{CONCLUSION}

The presented RP-HPLC method was proved to be simple, precise, accurate, and stability indicating for the simultaneous estimation of hydrocortisone and tetracycline pharmaceutical dosage form. The results of the study indicate that the proposed method of analysis can be used in quality control departments with respect to routine analysis for the assay of the ointment containing hydrocortisone and tetracycline.

\section{ACKNOWLEDGMENT}

The authors are grateful to Spectrum Pharma Research Solutions and Syntho Pharmaceuticals Pvt. Ltd. for providing the gift samples of drugs. Authors extend their gratitude to the Principal of Krishna Teja Pharmacy College for providing necessary facilities to carry out this work.

\section{AUTHORS' CONTRIBUTIONS}

All authors have contributed equally for this research article.

\section{CONFLICTS OF INTEREST}

Authors declare that no conflicts of interest exist in this research work.

\section{REFERENCES}

1. Niranjana ES, Sambath Kumar R, Sudha M, Venkateswaramurthy N. Review on clinically developing antibiotics. Int J App Pharm 2018;10:13-8

2. Nasir A, Muhammad S, Amjad H, Muhammad I, Muhammad A, Fawad RM, et al. Development and validation of a spectroscopic method for the simultaneous analysis of miconazole nitrate and hydrocortisone acetate in pharmaceutical dosage form. Trop J Pharm Res 2017;16:413-20.

3. Harika M, Kumar GS. Simultaneous UV-spectrophotometric estimation of hydrocortisone acetate and sulphacetamide sodium in combined dosage form. Int J Pharm Sci Res 2013;4:1901-4.

4. Ofori-Kwakye K, Adi-Dako O, Bekoe SO, Appiah E, Peprah P. Novel HPLC analysis of hydrocortisone in conventional and controlled release pharmaceutical preparation. J Pharm 2017;2017:1-8.

5. Rani NU, Rao JV. RP-HPLC determination of hydrocortisone in parenterals. Asian J Chem 2011;23:1407-8.

6. Sudhakar P, Pankaj S, Birendra S. Validation of stability indicating HPLC method for assay of fusidic acid, hydrocortisone acetate and potassium sorbate in topical pharmaceutical formulation. World $\mathrm{J}$ Pharm Pharm Sci 2016;5:1923-38.

7. Suryakant B, Rajput SJ. RP-HPLC method for simultaneous estimation of hydrocortisone acetate and miconazole nitrate in a cream formulation. Invent J 2014;3:1-4

8. Nassar AE, Varshney N, Getek T, Cheng L. Quantitative analysis of hydrocortisone in human urine using a high-performance liquid chromatographic-tandem mass spectrometric-atmospheric-pressure chemical ionization method. J Chromatogr Sci 2001;39:59-64

9. Genete G, Hymete A, Adnan AB. Development and validation of HPTLC assay method for simultaneous quantification of hydrocortisone and clotrimazole in cream and applying for stability indicating test. J Chil Chem Soc 2012;57:1199-203.

10. Emadhussien M. HPLC method validation for modernization of the tetracycline hydrochloride capsule USP monograph. Biomed Chromatogr 2014;52:239-44

11. Charoenraks T, Chuanuwatanakul S, Honda K, Yamaguchi Y, Chailapakul O. Analysis of tetracycline antibiotics using HPLC with pulsed amperometric detection. Anal Sci 2005;21:241-5.

12. ICH Harmonised Tripartite Guideline. Validation of Analytical Procedures: Text and Methodology Q2 (R1), International Conference on Harmonization; 2005. 